\title{
"Pananrang": A Guidance of Buginese Farmers in Farming
}

\author{
Apiaty Kamaluddin (Corresponding author) \\ Pepabri University, Jl. Cenderwasih No. 15 b-c, Makassar, 90221, Indonesia \\ Tel: +62-411-863382 Fax: +62-411-863382 E-mail: apiaty@icloud.com
}

\author{
Nurdiah Husnah \\ Badan Pengkajian Teknologi Pertanian (BPTP), Kementerian Pertanian Republik Indonesia, \\ Jl. Perintis Kemerdekaan Km 17.5 Makassar, 90245, Indonesia \\ Tel: +62-411-556449 Fax: +62-411-556449 E-mail: nurdiahhusnah@yahoo.com
}

Nurbaya Busthanul

Department of Agriculture Socio-Economics, Faculty of Agriculture, Hasanuddin University

Jl. Perintis Kemerdekaan Km 10, Makassar, 90241, Indonesia.

Tel: +62-411-580486 Fax: +62-411-580486 E-mail: nurbaya_busthanul@yahoo.com

M. Saleh S. Ali

Department of Agriculture Socio-Economics, Faculty of Agriculture, Hasanuddin University

Jl. Perintis Kemerdekaan Km 10, Makassar, 90241, Indonesia.

Tel: +62-411-580486 Fax: +62-411-580486 E-mail: saleh.assofie@gmail.com

(Received: Dec 8, 2015; Reviewed: Jan 27, 2016; Accepted: Nov 15, 2016)

\begin{abstract}
Each agrarian society had knowledge about how to interact with and understand nature. Some knowledge gained from nature were recorded and codified as inheritable knowledge from generation to generation. As in Buginese who lived at the southern part of the island of Sulawesi has such as knowledge that was named "Pananrang" or "Lontara Laongruma". The Pananrang was a knowledge developed based on lunar system (qamariah) as a reference for the farmer in estimating the season, time of planting and so on. The pananrang used as source of information in this article owned by a well experince and knowlegable farmer in District of Wajo, South Sulawesi Province, Indonesia. It was found that knowledge in panarang was developed based on the principle of regularity of events through 8 years $(\mathrm{si}$ pariama) observation. It contain rich of knowledge about farming and other everyday activities in yearly, monthly, and daily time period. It is found that the Pananrang which contains rich knowledge about farming that is still used by majority of Bugineses farmers as source of information in making decision on their farms. It is concluded that the pananrang is valuable and functional knowledge that can be used as a partner for modern scientific knowledge in promoting agriculture development.
\end{abstract}

Keywords: Pananrang; Indigenous Knowledge; Agriculture; Bugis-Makassar. 


\section{Introduction}

Every society including agrarian society have a knowledge of how to interact with and understand nature (Moghadam, 2015). For them, nature was perceived as "a good mother" (Verhagen, 2008) in guiding them to conduct and realize their will. Knowledge gained from nature were recorded and codified into an inheritable knowledge from generation to generation and it called as indigenous knowledge (Borkensha, Warren, Werner, 1980; Nakashima and Roue, 2002). There were some terms used to indicate this knowledge such as traditional knowledge (Lewis and Ramani, 2016; Ryser, 2011), local knowledge (Ali, 2000), traditional ecological knowledge (Kala 2012; Turner, Ignace \& Ignace, 2000), farmer knowledge (David and Asamoah 2011) and local wisdom (Dahliani et al., 2015; Mungmachon, 2012).

Whatever the term used, this knowledge has characteristics such as created by a group people who lives in close contact with nature over a long period of time; passed down from generation to generation; constant improvements and integrated to the existing; the creation and improvement is a group effort; stored in people' memories and activities; expressed in stories, songs, folklore, proverbs, dances, myths, cultural values, beliefs, rituals, community laws, local language and taxonomy, agricultural practices, equipment, materials, plant species, and animal breeds; and share and communicated orally (Lewis and Ramani 2016; Grenier 1988).

Indigenous knowledge is always placed in opposite side of western or mod- ern science which is more open, systematic and objective, dependent very much on being a detached centre of rationality and intelligence and part of the whole notion of modernity. Indigenous knowledge is seen to be closed, parochial, unintellectual, primitive and emotional and part of backward wayof life (Agrawal, 1995; Ellen and Harris, 2000; Herbert, 2000; Howes, 1979; Howes and Chambers, 1979; Mitchell, 1995; Warren, 1991).

Warren (1991) mentioned that scientific knowledge were developed by universities, government research centers, private companies base on scientific method which was deemed to be universal, have no relation to the social context or local culture, the potential for degradation was quite high, and it often produces something did not sustainable. Indigenous knowledge, on the other hand, developed by a society at a particular locality through the careful observation and experimentation over the years by associating natural phenomena around them. It is flexible and adaptable to local conditions, It is a social product and bound to the context of local culture or environment, oriented to meet the needs of local people and therefore more sustainable (Anonymous, 1994; Abinowo, 2000, Kamaluddin, 2012).

Ali (2000) stated that indigenous knowledge was functional knowledge of the local farmers in particular social and cultural system, developed contextually through experimentation (trial and error) which may be different from those developed by modern knowledge experts. Furthermore he said that the development of local knowledge is not based on the principles of reductionism 
or positivistic-deterministic used by most scholars of modern science, but it based on practical needs in accordance with their social and cultural systems.

According Prihandono (2012) Local knowledge is created through a long process, evolutionary, inherited and transfered through speech language / oral as well as direct practices from generation to generation (trans generations). Thus there is no copyright, the inventor did not known, but it perceived by society, and even become cultural values that guide people's behavior.

Today, more scientists and policy makers are aware of the contribution of indigenous knowledge for sustainable development (Viergever, 1999; Ali, 2000; Flora, 1992, Kloppenburg, 1991, Amrawaty, 2013; Husnah, 2014).

In agriculture, Indigenous knowledge gained global recognition through the United Nations Conference on Environment and Development (UNCED) in 1992 as an immensely valuable resource that provides humankind with insights on how communities interacted with their changing environment. However, much of this knowledge has never been systematically recorded and therefore are not readily accessible to agricultural researchers.

One form of indigenous that has been praticed by farmers around the world is knowledge about how to farm by using environmental information which was more known as indigenous agriculture calendar. In some areas of Indonesia, such knowledge is still used by farmers as a reference or guidelines in farming. For example, $P a$ nanrang (Bugis), Pranata Wangsa (Java),
Kerta-Masa (Bali), This knowledge is documented but no one knows when this knowledge documented.

The pananrang has been widely used by the Buginese farmers, but there were a limit number of publications about the pananrang in scientific journals. This paper is intended to contribute to this limitation.

This paper will discuss Pananrang as references of Bugis farmers in farming. Pananrang or so-called "Lontara Laongruma" which is comprise ordinances farming, climate change, the cycle of growing season, plant species are good for planting in certain seasons, including forecasts of pest attack. In Bugis, the term of pananrang derived from the word "tanra" means sign or marker. Therefore pananrang have meaning as "sign or marker" of incidents related to agricultural activities. Pananrang as an indigenous knowledge has historically been owned by buginese farmers in managing their farms.

\section{The Pananrang Used as Source of Information}

The pananrang or lontara alaurumang used in this paper is owned by La Tambo who stay in Wajo Regency. According La Tambo, this panarang he got from his father and written in bugis alphabet, no preamble or author mentioned on it. Every community in a particular locality in South Sulawesi is usually has own pananrang which was passed down from their ancestors.

\section{The Bugis Makassar Beliefs About Rice: Legend of Rice}

In the world of apotheosis, Dewi Sri or Shridevi is believed to be one of the gods that 
played an important role in human life. Dewi Sri as believed by many agrarian societies as the goddess of agriculture, the goddess of rice and rice fields, as well as the goddess of fertility. Dewi Sri believed to be a goddess who control the underground realm of the world, including the moon. Its role covers various aspects such as the mother goddess compassionate, protective, giving birth and life, control of foodstuffs on earth, especially rice.

Most legends about Dewi Sri related to Myths of the origin creation of the rice plant, staple food in some places in this world. The myth was started from the inability of snake to contribute labor to build the palace of Guru, the ruler of "upper world". Because the snake has no hands and feet to be used to work, the snake which was named as Anta goddess worried of getting a punishment from the Guru. He came to mourn and weep of the bad luck that happened to him. While wailing and crying, three drops of his tears turned into sparkling mustika. Actually the mustika was an eggshell that has a beautiful colour and snake god intends to presented as a gift to the Guru. In the course of delivering the eggs, he was attacked by crow so two eggs that stored in her mouth broke, and one remain and that safely reaches to Guru. Guru gladly accepted the mustika. But after knowing mustika is a magical egg, Guru ordered Anta to incubating the eggs. After a long period Anta incubating the egg, the egg was hatched. Miraculously a baby girl who was very pretty, cute, and adorable was coming out. The baby girl was immediately be appointed as a child" by Guru and his queen. Her name is Dewi Sri. As time passed,
Dewi Sri grown into an incredible beautiful young woman. She was kind, generous, smooth-spoken, gentility noble, luring all human beings. Every eye that looked at her, gods nor humans, immediately fell in love with the goddess (Taufik, 2008).

The beauty of Dewi Sri beats all heavenly nymphs and goddesses, and Guru also lured and secretly has a desire to marry her. Knowing it, other gods became worried because it would cause a scandal that might rocked and ruined the harmony in Booting Langi (Heaven). Then the gods was planned to separating Dewi Sri and Guru by using poison.

Finally, Dewi Sri died in the venom, and the gods immediately brought the body of the goddess down to earth and buried her in a hidden distant places. Because of the sanctity of Dewi Sri, from the her grave appears diverse plants that are useful to mankind, namely:

- From head grow palm trees;

- From the nose, lips and ears grow a variety crops of fragrant spices and vegetables;

- From the hair grow grass and a variety of beautiful and fragrant flowers;

- From the breasts grow fruits were ripe and sweet;

- From the arms and hands grow teak, sandalwood, and a variety of useful tree; of genitals appear palm tree or palm bersadap sweet sap;

- From the thighs grew various types of bamboo plants;

- From the legs appear a variety of root crops and potatoes; and

- From his navel grow the rice plant. 
4. Pananrang as Reference of Buginese Farmers

There are plenty of Pananrang manuscripts and even in every area which inhabited Buginese people at village level or family grove, has its own pananrang which was inherited from generation to generation, and it was written as a guidance in managing and cultivating land.

The manuscript does not have a preamble or introduction like a book, but directly show the content of the manuscript and the author's name is not listed. The owner of script pananrang believes that it was written by his ancestors but do not know whom the ancestors who wrote it.

Pananrang script writing was using Buginese alphabet, arabic letters and symbols of the muslim calendar. Therefore the existence pananrang although this has been known since a long time but codified in written culture after Islam arrived in South Sulawesi around the 16th century, during the reign of Sombayya Ri Gowa I Mangngarrangi Daeng Mangrabia Karaeng Lakiung Sultan Alauddin Awalul Islam king of Gowa 14th then spread into large kingdoms namely Luwu in South Sulawesi, Bone, Wajo, Soppeng and so forth..

Pananrang contains many agricultural activities linked to the start time doing agricultural enterprises in the range of annual, monthly, daily, even hourly.

\subsection{Annual Period}

In pananrang allaorumang, the month of Muharram is a month which is very important as a point marker in predicting events (related to agriculture) for the next year or determine the activities to be done in the year ahead. Which consist of eight name of years (sipariama) and each year is named in Arabic alphabet which has the characteristics as follows:

a. Year Alif (') (Taung Alipu): Called alif year if the rise sacred month (muharram) on tuesday. This year is believed will have a lot of rainfall but the short rains, many floods but the yield of rice and other crops in abundance. Alif year is considered as the best years in farming.

b. Year $H a$ (॰) (Taung Ha): Called $H a$ year if the emergence of sacred months (muharram) began saturday. In this year a lot of rain but the results somewhat less rice. Woody plants bear fruit. Many emerging diseases and blows cold air.

c. Year Jim (ج) (Taung Jim): Called Jim year if the rise sacred month (muharram) started on thursday. Jim year will bring enough rain, the wind was short, many fruiting plants while grain yield less than perfect. Social life "a little hot", need to be careful because a lot of children died. Buying and selling cheap price.

d. Year Zei (j) (Taung Zei): Called Zei year if the rise sacred month (muharram) starts on monday. In this year a lot of rain and flooding. At harvest is still a lot of rain. Ordinary mice attack. Rice yield was low. Many sick people but quickly recovered.

e. Year Dal Front (د) (Taung Daleng Riolo): Called Riola Daleng year if the rise sacred month (muharram) starting 
friday. In this year, rain is moderate, the wind blew a short, but fruit abundant. Yield of rice decreased because many hollow (makapa), heat and cold, good for planting corn.

f. Year Dal Rear (د) (Taung Daleng Rimonri): Called Daleng Rimonri year if the rise sacred month (muharaam) began on Friday. This year is indicated by short rainy day, the wind is weak but in case of strong winds will cause a lot of damage. Less flooding but the weather can be hot and cold. Rice yield can be good but it could also not good. Beggars lot of sustenance.

g. In Ba (ب) (Taung Ba): Called Ba year if the rise sacred months (muharram) starting on Wednesday. This year is mostly cold. Lots of rain in the sea or on land but many are also flooded. Many rice crops fail, the yiled of corn is good, fruit plants was spread on the ground. Hot air at all, the results of woody plants is not very good. Many emerging diseases.

h. In Wau (و) (Taung Wau): Called Wau year when the sacred months (muharram) starting on sunday. In this year usually has high rainfall, flooding, cold weather and the harvest was attacked by rat. Many emerging diseases such as sore eyes

\subsection{Monthly Period}

Bugis-Makassar Community using the issuance of the month as the basis for calculating events. Based on the principle of regular events (regularity of event) they predict what will happen every day for a month.
Every day is named based on the quality of the day which is tailored to the nature of humans or animals (Hamid, 2006). The following is one event per day forecasts in pananrang (lontara).

\subsection{Time Period in a Day}

For Bugis-Makassar, any time of the day contains its own meaning. A day is divided into five periods, namely the period of the morning (ele, between the hours of 6-8), the sun crept up period (abbuweng, between the hours of 8-11), a period of noon (tangasso, between 11-13 hours), the period after midday or just afternoon (lesang esso, between 13-15 hours), and the afternoon period (araweng, between 15-18 hours). There is no night period because no activities undertaken an it used only to rest. The content within each time period described in the following Table 2.

For example, if the calculation according to the time of planting will be conducted on Monday, then the best time to start planting that is between of $8.00-11.00$ am or at lesang esso (just afternoon), between 13.00$15.00 \mathrm{pm}$. If done on a Tuesday, so a good time is at $6.00-8.00 \mathrm{am}$ or at $13.00-15.00 \mathrm{pm}$ on the afternoon

\subsection{Timing for Planting}

In pananrang, knowing a good time to cultivate is based on the moon appearance at night and it might determines what plants are suitable for cultivate outlined below:

(1) Night appearance of the month (1-611-16-21-26) called esso lise sibawa ure' (contents and roots day); very good to start planting sweet potatoes, 
peanuts, or all of the plants that have tubers (fruit in the soil) and also good to keep fish.

(2) Hours of appearance month (2-7-1217-22-27) called esso aju (wood day); very good to begin to plant woody plants.

(3) Night emergence months (3-8-1318-23-28) called esso daung (leaf day); very good to start growing tobacco, tea, leaf lettuce, spinach, cabbage and other plants required or all of its leaves.

(4) Time of appearance month (4-9-14-2024-29) called esso unga (flower day); very good to start planting flowers or plants required all blossoms.

(5) Night emergence months (5-10-1520-25-30) called esso bua (fruit day); very good to start planting rice, cloves, corn, coffee, coconut and all plants are required fruit.

Table 1. Name of days and forecast events in a month period (30 days)

\begin{tabular}{|c|c|c|}
\hline $\begin{array}{l}\text { Night of } \\
\text { Month }\end{array}$ & Name of Day & Prediction/Forecast \\
\hline 1 & Esso annyarang (horse day) & $\begin{array}{l}\text { Not good to go abroad, either for government affairs, the } \\
\text { birthday of Adam }\end{array}$ \\
\hline 2 & Esso jonga (deer day) & Good for marriage, whether to sell, the birthday of Eve \\
\hline 3 & Esso macang (tiger day) & Not good for all kinds of jobs \\
\hline 4 & Esso meong (cat day) & Good for building houses, wedding \\
\hline 5 & Esso sukku (full day) & $\begin{array}{l}\text { Everything that done is not good, the sinking of the } \\
\text { prophet Noah }\end{array}$ \\
\hline 6 & Esso tedong (buffalo day) & $\begin{array}{l}\text { Good for the purchase of buffaloes, it is not good to go } \\
\text { abroad, and buy clothes }\end{array}$ \\
\hline 7 & Esso balawo (rat day) & Debt cannot be paid \\
\hline 8 & Esso lebbi (more year) & Good for travelling and marriage \\
\hline 9 & Esso asu (dog day) & Good for travelling \\
\hline 10 & Esso naga (lion day) & Good to go abroad, build a house and planting \\
\hline 11 & Esso bebe (stupid day) & $\begin{array}{l}\text { The day of Adam enter paradise, a good time for going to } \\
\text { the beach }\end{array}$ \\
\hline 12 & Esso macang (tiger day) & Good for selling \\
\hline 13 & Esso naga (dragon day) & Not good for go abroad, a little of kindness \\
\hline 14 & Esso singa (lion) & Good for every works except to go abroad \\
\hline 15 & Esso jonga (deer day) & Good time to build a boat \\
\hline 16 & Esso bawi (pig day) & Good time for growing plants \\
\hline 17 & Esso manu-manu (bird day) & Good for all the work, including abroad, apply, to the king. \\
\hline 18 & Esso wani (Bee day) & Good to go abroad, a wedding, build houses, and plant \\
\hline 19 & Esso balipeng (centipede day) & Good to propose \\
\hline 20 & Esso ala-ala (domestic animal day) & $\begin{array}{l}\text { Good time to propose and people will be happy in } \\
\text { welcoming us }\end{array}$ \\
\hline 21 & Esso assai (true day) & Less of luck \\
\hline 22 & Esso dongi (sparrow day) & $\begin{array}{l}\text { Good to go abroad, building a house, marriage, and to } \\
\text { plant. }\end{array}$ \\
\hline 23 & Esso ancale (grasshopper day) & $\begin{array}{l}\text { Good to go abroad planting, marriage, and not good for the } \\
\text { other. }\end{array}$ \\
\hline 24 & Esso malampe (long day) & Less of luck \\
\hline 25 & Esso pasei/taccipi (pinched day) & Less of luck \\
\hline 26 & Esso tuppang (frog day) & $\begin{array}{l}\text { Good to go abroad, planting, debt will be soon be payed, } \\
\text { good time for fishing }\end{array}$ \\
\hline 27 & Esso ule' (caterpillar day) & $\begin{array}{l}\text { Every little thing will doing well, good time to abroad and } \\
\text { planting, debt will be soon be payed }\end{array}$ \\
\hline 28 & Esso kalapua (turtle day) & $\begin{array}{l}\text { Every little thing will doing well, good time to abroad and } \\
\text { planting, debt will be soon be payed }\end{array}$ \\
\hline 29 & Esso iti' (duck day) & Not good to go abroad and less of luck \\
\hline 30 & Esso manu' (cock day) & $\begin{array}{l}\text { Good time for cutting wood. Baby who born will get good } \\
\text { fortune. }\end{array}$ \\
\hline
\end{tabular}

Source: La Tambo'lontara; Abu Hamid 2006. 
Table 2. Quality of time (hour) in a day period

\begin{tabular}{cccccc}
\hline Day/Hour & $\begin{array}{c}\text { Ele } \\
\text { (Morning) } \\
\mathbf{6 - 8}\end{array}$ & $\begin{array}{c}\text { Abbuweng } \\
\text { (Sun Crep Up) } \\
\mathbf{8 - 1 1}\end{array}$ & $\begin{array}{c}\text { Tangasso } \\
\text { (Noon) } \\
\mathbf{1 1 ~ - ~ 1 3}\end{array}$ & $\begin{array}{c}\text { Lesang Esso } \\
\text { (Just Afternoon) } \\
\mathbf{1 3 - 1 5}\end{array}$ & $\begin{array}{c}\text { Araweng } \\
\text { (Afternoon) } \\
\mathbf{1 5}-\mathbf{1 8}\end{array}$ \\
\hline $\begin{array}{c}\text { Jum'at } \\
\text { (Friday) }\end{array}$ & $\begin{array}{c}\text { Mate } \\
\text { (die) }\end{array}$ & $\begin{array}{c}\text { Tuwo } \\
\text { (life) }\end{array}$ & $\begin{array}{c}\text { Maddarah } \\
\text { (bloody) }\end{array}$ & $\begin{array}{c}\text { Lobbang } \\
\text { (empty) }\end{array}$ & $\begin{array}{c}\text { Mallise } \\
\text { (full) }\end{array}$ \\
$\begin{array}{c}\text { Sabtu } \\
\text { (Saturday) }\end{array}$ & $\begin{array}{c}\text { Maddara } \\
\text { (bloody) }\end{array}$ & $\begin{array}{c}\text { Tuwo } \\
\text { (life) }\end{array}$ & $\begin{array}{c}\text { Mate } \\
\text { (die) }\end{array}$ & $\begin{array}{c}\text { Mallise } \\
\text { (full) }\end{array}$ & $\begin{array}{c}\text { Lobbang } \\
\text { (empty) }\end{array}$ \\
$\begin{array}{c}\text { Ahad } \\
\text { (Sunday) }\end{array}$ & $\begin{array}{c}\text { Mallise } \\
\text { (full) }\end{array}$ & $\begin{array}{c}\text { Mate } \\
\text { (die) }\end{array}$ & $\begin{array}{c}\text { Tuwo } \\
\text { (life) }\end{array}$ & $\begin{array}{c}\text { Maddara } \\
\text { (bloody) }\end{array}$ & $\begin{array}{c}\text { Lobbang } \\
\text { (empty) }\end{array}$ \\
$\begin{array}{c}\text { Senin } \\
\text { (Monday) }\end{array}$ & $\begin{array}{c}\text { Lobbang } \\
\text { (empty) }\end{array}$ & $\begin{array}{c}\text { Tuwo } \\
\text { (life) }\end{array}$ & $\begin{array}{c}\text { Maddarah } \\
\text { (bloody) }\end{array}$ & $\begin{array}{c}\text { Mallise } \\
\text { (full) }\end{array}$ & $\begin{array}{c}\text { Mate } \\
\text { (die) }\end{array}$ \\
$\begin{array}{c}\text { Selasa } \\
\text { (Tuesday) }\end{array}$ & $\begin{array}{c}\text { Mallise } \\
\text { (full) }\end{array}$ & $\begin{array}{c}\text { Mate } \\
\text { (die) }\end{array}$ & $\begin{array}{c}\text { Lobbang } \\
\text { (empty) }\end{array}$ & $\begin{array}{c}\text { Tuwo } \\
\text { (life) }\end{array}$ & $\begin{array}{c}\text { Maddara } \\
\text { (bloody) }\end{array}$ \\
$\begin{array}{c}\text { Rabu } \\
\text { (Wednesday) }\end{array}$ & $\begin{array}{c}\text { Mate } \\
\text { (die) }\end{array}$ & $\begin{array}{c}\text { Tuwo } \\
\text { (life) }\end{array}$ & $\begin{array}{c}\text { Maddara } \\
\text { (bloody) }\end{array}$ & $\begin{array}{c}\text { Lobbang } \\
\text { (empty) }\end{array}$ & $\begin{array}{c}\text { Mallise } \\
\text { (full) }\end{array}$ \\
$\begin{array}{c}\text { Kamis } \\
\text { (Thursday) }\end{array}$ & $\begin{array}{c}\text { Mallise } \\
\text { (full) }\end{array}$ & $\begin{array}{c}\text { Lobbang } \\
\text { (empty) }\end{array}$ & $\begin{array}{c}\text { Mate } \\
\text { (die) }\end{array}$ & $\begin{array}{c}\text { Tuwo } \\
\text { (life) }\end{array}$ & $\begin{array}{c}\text { Maddara } \\
\text { (bloody) }\end{array}$ \\
\hline
\end{tabular}

Source: La Tambo'lontara; Abu Hamid 2006.

\subsection{Day of Abstinence}

In any year or month there are several days that prohibited or not allowed to conduct activities. This day is called abstinence day (esso nakassa). Day of abstinence in the annual cycle days from the issuance primarily the month of Muharram. For the Bugis Makassar, it was the day that forbiden to do farming, fishing, building a house, mating and so on. For example, when the day of the month of Muharram began on monday, then the whole monday in one year until the next month of Muharram is forbiden to work or to do an activity.

\section{Conclusion}

Pananrang still widely used by farmers as a reference in determining activities in farming or other activities. Due to the ecological conditions of each region in the area of South Sulawesi, where the Bugis Makassar lived, then each region has its own pananrang which was the result of notes and observations from their ancestors.
Recording in pananrang follow the principle of regularity of events which includes 8-year monitoring period which was called sipariama, and each year was named with Arabic alphabet.

Muharram in Buginese community has a very important and significant month than any other month in determining farming activities and others. The beginning of the occurance of Muharram (the first day of Muharram) was seen as a day of abstinence from which to undertake activities including agricultural activities.

Bugis people divided the period of time during the day as much as 5 periods of the morning (ele, between the hours of 6-8), the sun crept up period (abbuweng, between the hours of 8-11), a period of noon (tangasso, between 11-13 hours), period after midday (lesang esso, between 13-15 hours), and the afternoon period (araweng, between 15-18 hours). Each of these periods on a daily basis have their respective meanings set forth in the dead time (mate), the life time 
(Tuwo), time containing (mallise), idle time (lobbang), and the bloody time (maddara).

Each plant has a great time to plant it. Plants that result in the soil as umbii tubers and peanuts should be planted on the content and the root (esso lise sibawa ure '). Plants that are needed such as wooden trunk should be planted on esso aju (wood day). The results are expected to cider plant leaves as vegetables grown on the leaf (esso daung). Plants are the results expected from flowers like flowers planted in the flower (esso unga) and other plants with the results expected from fruit such as rice, corn, coconut, coffee and so planted in the fruit (esso bua).

Pananrang still believed by Buginese farmers as a reference in making decision how to start an agricultural activity, and it can be used as partner with scientific knowledge in agriculture development.

\section{References}

Abinowo. U. (2000). The Future of Agricultural Model. Alternative Solutions to Face the Free Trade. Integrated Agricultural Development Centers. SPATPasuruan.

Ali, M. S. S,. (2000). "Local Knowledge and Sustainable Agricultural Development; The Perspective of Marginal People". Inauguration Professorship Speech, Hasanuddin University. Makassar.

Amrawaty, A., Ali, M. S. S., Husnah, N., (2014). "Build Synergy Between Local and Modern Knowledge In Developing Beef Cattle." International Journal of Scientific and Technology Research. 3 (11): 196-199.
Anonymous, (nd). Lontara Allaorumang Owned La Tambo (not published).

Brokensha, D., Warren, D. and Werner, O. (eds), (1980). Indigenous Knowledge Systems and Development. University Press of America, New York.

Dahliani, D., Soemarno, I., Setijanti, P., (2015). "Local Wisdom in Built Environment in Globalization Era." International Journal of Education and Research. Vol. 3 No. 6, June.

Daljoeni. (1984). "Pranatamangsa, The Javanese Agricultural Calendar-Its Bioclimatological and Sociocultural Function in Developing Rural Life." Environmentalist Journal, vol. 4, Issue 7 Supplement, pp. 15-18.

David, S. and Asamoah, C. (2011). "Farmer Knowledge as an Early Indicator Of IPM Adoption: A Case Study From Cocoa Farmer Field Schools in Ghana." Journal of Sustainable Development in Africa. Volume 13, No.4.

Flora, Cornelia B. (1992). "Reconstructing Agriculture: The Case for Local Knowledge”. Rural Sociology 57 (1): 92- 97.

Grenier, L. (1988). Working With Indigenous Knowledge: A Guide for Researchers. International Development Research.

Husnah, N., Ali, M. S. S, Salman, D., Hijjang, P., (2014). "Merging Indigenous and Modern Knowledge in Agricultural Development." International Journal of Agriculture System. Volume 2 (2): 141-151

Kamaluddin, A., Ala, A., Ali, M.S.S., Salman, D., (2012). "The Adaptation of Rice Paddy Farmers Towards Cli- 
mate Change." American-Eurasian J. Agric. \& Environ. Sci., 12 (7): 967972.

Kloppenburg, J. (1991). "Social Theory and the De / Reconstruction of Agricultural Science: Local Knowledge for an Alternative Agriculture." Rural Sociology 56 (4): 519-548.

Levis, W.H and Ramani, V. (2016) Ethics and Practice In Ethnobiology: Analysis of The International Cooperative Biodiversity Group Project In Peru. https:// law.wustl. edu/centeris/Papers/.../PDFWrdDoc/lewisramani. Retrived 21 Oct. 2016.

Moghadam, D.M; Sing, H.J; and Wan Yahya, W.R. (2015). "A Brief Discussion on Human/Nature Relationship." International Journal of Humanities and Social Science Vol. 5, No. 6. (June).

Mungmachon, R., (2012). "Knowledge and Local Wisdom: Community Treasure." International Journal of Humanities and Social Science Vol. 2 No. 13; July. Nakashima, D and Roue, M. (2002). "Indigenous Knowledge, Peoples and Sustainable Practice." In Social and Economic Dimensions of Global Environmental Change. Edited by Peter Timmerman in Encyclopedia of Global Environmental Change (ISBN 0-471-977969). Volume 5, pp 314 - 324. John Wiley \& Sons, Ltd, Chichester, 2002

Prihandono, A,. (2012). "Local Wisdom Institution Technology and Institutional at Some Traditional House in East Indonesia." Journal of Socio-Economic
Public Works, Vol.4 No.1, April 2012.

Retnowati, A., Anantasari. E., Marfai, M. A., Dittmann, A. (2014). "Environmental Ethics in Local Knowledge Responding to Climate Change: An Understanding of Seasonal Traditional Calendar PranotoMongso and its Phenology in Karst Area of GunungKidul, Yogyakarta, Indonesia." Procedia Environmental Sciences 20, 785 - 794

Ryser, R. C. (2011). "Indigenous Peoples and Traditional Knowledge." Berkshire Encyclopedia of Sustainability 5/10, Ecosystem Management and Sustainability.

Taufik, R.M., Asri, T. (2008). "Myth Nyi Pohaci." Journal of Plumbers Images. Available in: https://goo.gl/OYF5Bc Retrived on July 20, 2012.

Verhagen, F.C. (2008). "Worldviews and Metaphors in The Human-Nature Relationship: An Ecolinguistic Exploration Through the Ages." Language \& Ecology Vol. 2 no. 3.

Viergever, M. (1999). "Indigenous Knowledge: An Interpretation of Views From Indigenous Peoples". Pp.333- 359 in Semali, Ladislaus M. and Joe L. Kincheloe (Eds.). What is Indigenous Knowledge? Voices From the Academy. New York and London. Falmer Press.

Warren, D.M. (1991). Using Indigenous Knowledge in Agricultural Development ', World Bank Discussion Papers. The World Bank, Washington, D.C. 